\title{
National Innovation System and Its Structure
}

\author{
Garifullin I.N.a \\ Ablaev I.M. ${ }^{b}$ \\ ab Kazan Federal University, Institute of Management, Economics and Finance, Kazan, 420008, Russia \\ Email: ilsurgarifullin@yandex.ru
}

\section{Doi:10.5901/mjss.2015.v6n1s3p426}

\begin{abstract}
The article dwells on the subject of national innovation system, discloses its essence and structure. The given analysis reveals the complexity of the innovation system of the state, defines its integral constituents and outlines the indispensable conditions for the effective development of the national economy by means of creation of favourable innovative environment
\end{abstract}

Keywords: national innovation system, regional economy, innovation economy, innovation cluster

\section{Introduction}

The economic reforms undertaken in the Russian Federation for the last decades caused the serious structural transformations both in the state economy in general and in its single sectors in particular. The government set the strategic goal of transition of the national economy of Russia to an innovative phase of development. Accordingly, at present time in the economic studies there is a necessity for theoretic justification and methodological substantiation of this transition at all the levels: macro, meso and at the level of municipalities under conditions of preservation of all the contradictory approaches and theoretic views on evaluation of the innovation system of the state.

In this regard there is a need for specification of methodological approaches and for disclosure of the economic essence of the concept named "innovation system" that receives the ambiguous interpretation in the modern economic literature both in Russia and abroad.

\section{Theory}

In the economic literature the term "national innovation system" is often referenced to denote a unity of enterprises of various patterns of ownership that individually or through interaction with each other provide the formation and dispersion of innovation technologies within a definite state. National innovation system encourages the implementation of the derived technologies into production and development of new products saleable in the world market. Among such organizations there are scientific institutions (R\&D institutes, institutes of higher education, private laboratories, scientific departments of corporations - all of them can be summarized under the term "creators of innovation"); then, "infrastructural" enterprises - technoparks, innovative technology centers, venture funds; agencies conditioning the innovation climate and governmental bodies: ministries and specialized departments; the small, medium and big businesses as the first and the final consumer and as one of the primary initiators of innovation.

The concept of national innovation system was introduced in the economic literature by $\mathrm{C}$. Freeman, developed by B.-A.Lundvall and R. Nelson. National innovation system, according to C.Freeman, is a complex system of economic subjects and public institutions that take part in production, storage, distribution and transformation of knowledge into new technologies, goods and services consumed by society [1].

According to the classical definitions given by B.-A.Lundvall and R. Nelson, innovation is a complex process of introduction of new technologies and knowledge that unite various elements - firms, creators of innovations, technological and analytical centers deeply intertwined with each other - all this together compose the innovation system [4].

In N.I.Ivanova's opinion, national innovation system stands for the entity of interrelated organizations (structures), engaged in production and sales of the scientific knowledge and technologies within the national boundaries. At the same time, the national innovation system is the complex of institutions of legislative, financial and social character, that in 
aggregate support the innovation processes and have strong national roots, traditions, political and cultural peculiarities [3].

The theoretical interpretation of national innovation system was embodied in the working state acts. This term occurs in The Foundations of the policy of the Russian Federation in the field of science and technology for the period up to 2010 and further perspective (ratified in March 30, 2002, № Pr-576), where the necessity of formation of national innovation system was claimed as one of the crucial directions of the state policy in the sphere of science and technology.

In the international practice the following definition is in usage: "the national innovation system is a whole of institutions belonging to the private and the public sectors, that individually or in interaction with each other condition the development and spread of new technologies within the boundaries of a certain state" [5].

Thus, in accordance with its constituents the national innovation system corresponds to a complex of institutions of economic, legislative, financial and social character that support the innovation processes. It is a whole of institutions, i.e. a whole of rules and conditions, in accordance with the organizations function. Its goal is development and spread of the new technologies, innovations and organizations of management within a certain state in the form of the object of intellectual property.

\section{Results}

As an open system NIS reveals itself in the interaction of organizations (structures), of various forms of property engaged in creation of scientific knowledge, objects of intellectual property and their pre-market grounding within the national boundaries. The results of the activity of the national innovation system are as follows: new technologies, new knowledge, know-how, new generation products and finally - a new technological structure that revolutionizes the sectorial structure of the economy, the quality of the gross domestic product and the gross national product.

The substitution of the technological structures as a rule requires certain changes in the social and institutional systems. These changes facilitate the mass introduction of the technologies of new structure and spread of the appropriate types of consumption and modes of life. And what comes next is the phase of fast expansion of this new technological structure. It turns into a basis for the economic growth and takes the leading position in the structure of economy. The phase of growth entails the readjustment of the existing technological chains in compliance with new needs. Simultaneously this leads to the emergence of the upcoming, the newest, technological structure which exists in embryo until the dominating technological structure reaches its limits to growth, and then the next technological revolution starts. This process is accompanied by the formation of a new infrastructure, which overcomes the limits of the previous one and leads to the transition to new types of utilities that serve the foundation for origination of the following technological structure [2].

Among the organizations that may be involved as the subjects of national innovation system there are departments of the large companies engaged in creation and refinement of the innovation processes and the products within the company, laboratories and university departments, academic units, technoparks, innovative small businesses engaged in commercialization of the objects of the intellectual property, and the bulk of institutions of legislative, financial and social character that serve to support the innovation processes.

The results of the activity of the national innovation system are integral to the national wealth. In the course of this activity the scientific knowledge is reproduced and accumulated, that hereafter shape into intangible assets which in their turn contribute to the national property and affect the gross domestic product.

Hence, the national innovation system is a set of institutions, the rules and terms of their interrelations, that within the national boundaries provide for the origination of such intangible assets that as a part of the national patrimony can be called the innovation in the form of intellectual property ready for commercialization.

Upon consideration of the key elements constituting the "innovation system" it is necessary to examine their interrelationship which ultimately determines the structure of the innovation system. Below Figure 1 represents the structure of the national innovation system, and thereupon a question arises: what is the core of this system, its "motive power" and which elements are ancillary.

Taking into account the common definition of term "innovation" given by J. Schumpeter, we can suggest that as well as in innovation itself the core element of the innovation system, its driving force is the innovator. In our opinion this point of view is correct. But the matter is who can perform the functions of the innovator: the state in the person of officials of different ranks (Peter the First, F.Stolypin, L.Beriya) or the scientist-inventor (S.Korolyov), or the entrepreneur (G.Ford). But the precise definition of the main driving force of the system can be given with due regard for all the mentioned subjects. Depending on the stage of industrial cycle (crisis, depression, recovery and growth) various subjects may 
represent themselves as the innovator. The phase of crisis and depression, when the entrepreneur struggles for survival, is characterized by the innovation pause. At this time temporarily the state becomes the innovator. Within the phase of recovery and growth the part of innovator is performed by the entrepreneur together with the innovator.

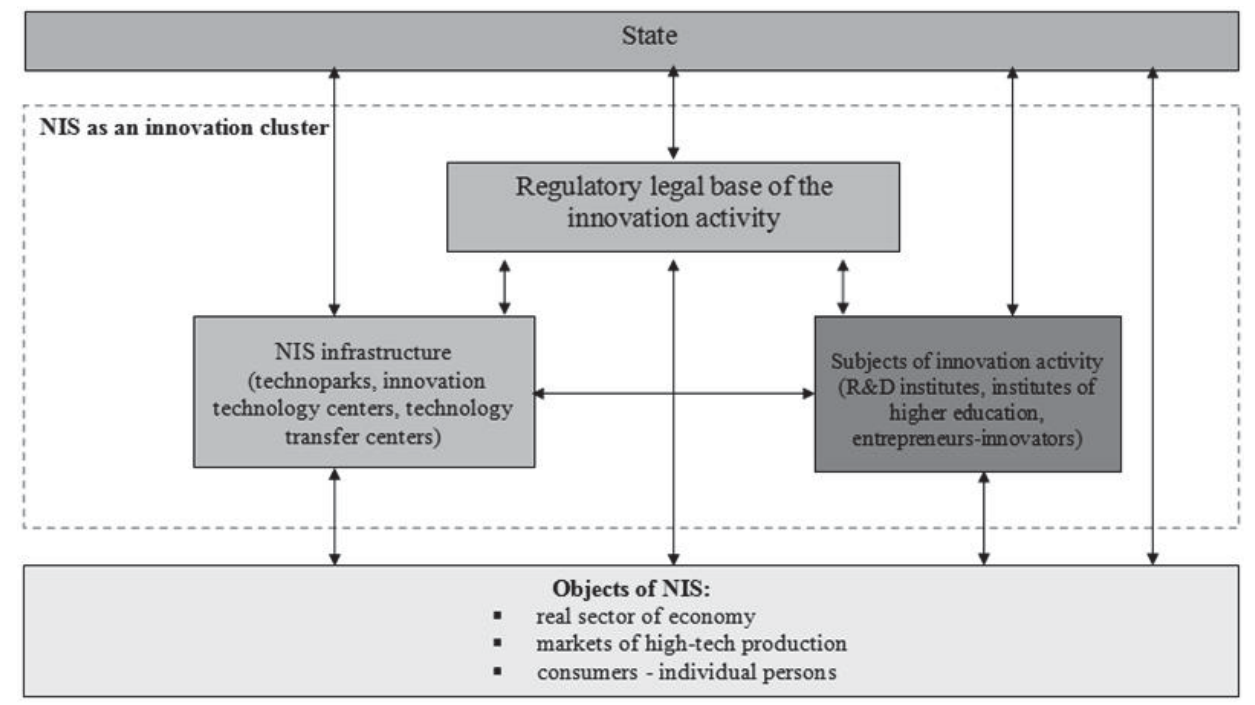

Fig. 1. Structure of the national innovation system (NIS)

\section{Conclusions}

Regardless of the current economic situation the state is to create and coordinate the work of various subjects of the system, create the necessary prerequisites for the development of the innovation: by means of support of the R\&D institutions, by means of financing of the venture funds, by stimulating (in the first place - financially) the activity of the higher education establishments (that provide the personnel potential for innovation activities), and by legal regulation in the sphere of tax, patent and customs policy. The degree of this participation may vary on the territory of the state. Moreover, by means of creation of the national federal and regional purpose-oriented programs (such as the development of space, of the military-industrial complex, the energy-saving policy etc.) the state as an external state customer must set the vector for the national innovation system development that would facilitate the sci-tech development of the national economy. But without the production by the scientist-innovator (i.e. properly R\&D) there will be nothing to implement, while without the entrepreneur there will be no motive power and private interest for sales. The commodity-money turnover is usually initiated by the motivation for profit, but the state is an inefficient entrepreneur, because it is represented by the officials who rotate more often than the businessmen become bankrupt. The official in any state is the ersatz owner and takes neither financial responsibility, no liability for the consequences of the decisionmaking. Therefore the mission of the state is to create the effective conditions for the economic development and for the national innovation system development in particular.

\section{References}

Freeman C., Technology Policy and Economic Performance: Lessons from Japan, London: Frances Pinter, 1987.

Glazyev S. The global economic crisis as the process of the technological structures interchange. Voprosy economiki, № 3, 2009

Ivanova N.I. National Innovation Systems // Voprosy ekonomiki. - № 7. - 2001. - p. 61.

Lundvall B.-A., National Systems of Innovation. Towards a Theory of Innovation and Interactive Learning, London: Pinter Publishers, 1992; Nelson R., ed., National Innovation Systems: A Comparative Analysis, N.Y.: Oxford University Press, 1993.

National Innovation Systems // Innovation in science, technology and industry, 1997. Direct link: http://www.oecd.org/science/inno/ 2101733.pdf.

Ablaev I.M., Khovanskaya E.S. Essence and Economical Substance of Innovative Cluster in Territorially Localized Business System// Mediterranean Journal of Social Sciences.- Vol.5, No12, (2014)-pp.159 - 162.

Fakhrutdinova E., Severyanov O., Shigabutdinov A., Fakhrutdinov R. The crisis of 1998 in Russia: political intervention and its implications. Life Science Journal 2014; 11(6s): 442 - 447. 
Sadriev A.R., Pratchenko O.V. Idea Management in the System of Innovative Management// Mediterranean Journal of Social Sciences.Vol.5, No12, (2014)-pp.155 - 158.

Bagautdinova, N., Tsaregorodtsev E., Kulalayeva I., Arzhantseva N. Assessment of Mutual Probabilistic Influence of Volatility of Official Price for Precious Metals on the Market Value of the Bi-Currency Basket// Mediterranean Journal of Social Sciences.- Vol.5, No12, (2014)-pp.33-38.

Maksutina E.V., Makarov A.N., Nazmeev E.F., Alpatova E.S. Assessment of economic efficiency of investments into the human capital in modern conditions. Life Science Journal 2014; 11 (6s): 376-379.

Yafizova D.A., Shigabutdinov A.F. Revisiting the issue of the long-run competitiveness of the National Petrochemical Complex/ Life Science Journal 2014;11(8s), pp. 168-171.

Shigabieva A.M., Safiullin L.N., Mazitov V.M., Saipullaev U.A. Some methodological foundation of an innovation theory. Life Science Journal 2014; 11(6s): 388 - 391.

Panasyuk, M.V., Pudovik, E.M., Malganova, I.G. (2014). Modified index method in scenarios of regional socio-economic development. Mediterranean Journal of Social Sciences, 5 (18 SPEC. ISSUE), pp. 331-334.

Khairullov, D.S., Saipullaev, U.A. (2014). Management of social and economic security of the region. Mediterranean Journal of Social Sciences, 5 (12), pp. 177-182. 